Do Liberals Play Nice?

The Effects of Party and Political Ideology in Public Goods and Trust Games

\author{
Lisa R. Anderson \\ College of William and Mary \\ Jennifer M. Mellor \\ College of William and Mary \\ Jeffrey Milyo \\ University of Missouri
}

College of William and Mary

Department of Economics

Working Paper Number 7

November 2004 
COLLEGE OF WILLIAM AND MARY

DEPARTMENT OF ECONOMICS

WORKING PAPER \# 7

November 2004

\title{
Do Liberals Play Nice? \\ The Effects of Party and Political Ideology in Public Goods and Trust Games
}

\begin{abstract}
A popular perception among the American electorate is that Democrats and liberals are more caring and kind-hearted than Republicans and conservatives. This stems in part from the consistent finding in opinion surveys that left-leaning individuals tend to support increased public spending on social programs. In this study, we put conventional wisdom to the test by examining differences in the behavior of liberal versus conservative subjects in two classic experimental settings: the public goods game and the bilateral trust game. First, we test whether Democrats or liberals are more likely to contribute to a group account when such actions are contrary to self-interest. Next, we test whether Democrats and liberals choose to trust strangers or to behave in a trustworthy fashion, despite monetary incentives to the contrary. To address the concern that liberals may not behave more compassionately in the artificially egalitarian setting of the laboratory, we induce inequality among subjects by manipulating the show-up fee paid to all participants. We find that despite conventional wisdom and survey evidence, there is no tendency for adherents of either major party to play nice, nor do self-described liberals have a greater tendency to make contributions in a public goods experiment. However, in keeping with conventional wisdom (but not necessarily national survey results), we find some evidence that self-described liberals behave in a more trusting and trustworthy manner.
\end{abstract}

JEL Codes: C9, H4

Keywords: public goods, experiment, political ideology

Lisa R. Anderson

Department of Economics

College of William and Mary

P.O. Box 8795

Williamsburg, VA 23187-8795

lrande@wm.edu

Jeffrey Milyo

Department of Economics

and Truman School of Public Affairs

University of Missouri

118 Professional Building

Columbia, MO 65211

milyoj@missouri.edu
Jennifer M. Mellor

Department of Economics

College of William and Mary

P.O. Box 8795

Williamsburg, VA 23187-8795

jmmell@wm.edu 


\section{Do Liberals Play Nice? \\ The Effects of Party and Political Ideology in Public Goods and Trust Games}

Anderson, Mellor and Milyo

“Jesus was a liberal” — Alan Colmes, political commentator for Fox News ${ }^{1}$

\section{Introduction}

Democrats and liberals are generally understood to be more caring and kind than Republicans and conservatives; for example, even conservative author and media personality Ben Wattenberg has acknowledged that "the word 'conservative' conjures up images of the miserly Ebenezer Scrooge, while 'liberal' brings to mind kindly Santa Claus.” (PBS Think-Tank, 1995). This perception of Democrats and liberals as more other-regarding, while not universal, ${ }^{2}$ is pervasive enough that George W. Bush, while campaigning for the Republican nomination for president, adopted the moniker of a "compassionate conservative" to counter such stereotypes. But are left-leaning individuals really more generous and trusting?

We put conventional wisdom to the test by examining differences in the behavior of liberal versus conservative subjects in two classic experimental settings: the public goods game and the bilateral trust game. In the first set of experiments, we test whether Democrats or liberals are more likely to contribute to a group account when such actions are contrary to self-interest. In the latter set of experiments, we test whether Democrats and liberals choose to trust strangers

${ }^{1}$ From a chapter heading in Colmes (2003).

${ }^{2}$ Some would argue that liberals are indeed generous, albeit with others' money. This opposing view is most succinctly articulated by the conservative author and provocateur, Ann Coulter: “...there is only one thing wrong with liberals: They're no good.” (Coulter, 2002). 
or to behave in a trustworthy fashion, despite monetary incentives to the contrary. The question of whether political attributes influence behavior is interesting in itself, but also because experimental subjects are often drawn from a pool of atypically liberal college students. To the extent that political attitudes are an important determinant of behavior, experimental researchers must take added caution in applying findings to contexts outside the lab. Similar concerns regarding the "indoctrinating effect" of economic instruction received by the pool of likely experimental subjects have generated an extensive literature, ${ }^{3}$ but no previous published work systematically examines the effects of political party or ideology. ${ }^{4}$ Finally, our study complements recent experimental work on the validity of survey measures of trust (Glaeser, et al. 2000 and Anderson, Mellor and Milyo 2004a), in that we test whether the self-proclaimed generosity of Democrats and liberals is just cheap talk.

While an experimental test of the proposition that liberals "play nice" has many advantages over non-experimental techniques, one drawback is that the true association between ideology and generosity may be a response to perceived inequities in the social environment. Therefore, liberals may not behave more compassionately in the artificially egalitarian setting of the laboratory. In order to address this concern, we induce inequality among subjects by

${ }^{3}$ Findings on the "indoctrination effect" are quite mixed; for a recent review and novel evidence contra the existence of such an effect, see Frey and Meier (2003).

${ }^{4}$ There are only two related studies of which we are aware: Mestelman and Feeny (1988) report some suggestive evidence that political ideology influences free-riding in a public goods game, while Fehr et al. (2003) show that major party affiliation among experimental subjects in Germany is associated with trust and trustworthiness in a one-shot trust game. However, the latter study does not estimate the effects of left-leaning versus right-leaning party affiliation or ideology. 
manipulating the show-up fee paid to all participants. ${ }^{5}$ This experimental design allows us to test whether liberals play more nicely in non-egalitarian versus egalitarian settings.

In the next section we describe evidence from national surveys on the relationship between political attitudes and support for government spending and trust. In turn, we describe the study design, survey results and experimental results. In short, we find that despite conventional wisdom and survey evidence, there is no tendency for adherents of either major party to play nice, nor do self-described liberals have a greater tendency to make contributions in a public goods experiment. However, in keeping with conventional wisdom (but not necessarily national survey results), we find some evidence that self-described liberals behave in a more trusting and trustworthy manner.

\section{Political Party and Ideology: Evidence from National Surveys}

The popular perception that Democrats and liberals are more kindhearted stems in part from the consistent finding in opinion surveys that left-leaning individuals tend to support increased public spending on social programs. Such associations in survey data are well known and are stock material in popular textbook accounts of American politics (e.g., Wilson and Dilulio 2004). However, it is less obvious that left-leaning individuals are more trusting, even though trust is often considered part and parcel with generosity. In fact, recent research shows that minorities, lower income individuals and women (i.e., the core constituency of the Democrat party) tend to exhibit less trusting attitudes (Alesina and La Ferrara 1999). On the other hand, generalized trust is also well known to be lowest in the South, a bastion of ideological

${ }^{5}$ Elsewhere, we have demonstrated that such manipulations influence contribution levels (Anderson, Mellor and Milyo 2004a and 2004b). 
conservatism (Putnam 2000). Consequently, survey evidence lends at best mixed support for the conventional view that Democrats and liberals are more trusting. As we will illustrate shortly, the patterns found in national survey data are also observed among our experimental subjects.

In order to provide a baseline for comparing the representativeness of the opinions of our experimental subjects, we examine the correlation of political party and ideology with support for public goods and a common attitudinal measure of trust. For this exercise, we employ data from two national opinion surveys, the 1972-2002 General Social Survey (GSS) and the 2000 National Election Survey (NES).

We first consider the evidence from the GSS; this cumulated data set has the advantage that we can separately analyze the opinions of college-aged individuals (18 to 22 year-olds). We measure opinions about spending on public programs by constructing a count of the number of times an individual states that there is currently "too little government spending" on any of eight major programmatic areas (arms, education, foreign aid, health, social security, transportation and welfare); in a similar fashion, we also measure support for the subset of social spending categories (education, health, social security and welfare). The results presented in Table 1 are quite consistent with textbook accounts: Democrats and liberals are more supportive of government spending, particularly on social programs. These proclivities are likewise present among 18 to 22 year-olds.

Next, we follow Putnam (2000) and others in measuring trust by agreement with the statement "in general, most people can be trusted." Contrary to common stereotypes, panel A of 
Table 1 shows that Republicans are more trusting of others, while Democrats are less so. ${ }^{6}$ In addition, there is a weak negative correlation between liberal ideology and trust. Panel B reveals that young Republicans are likewise more trusting, but in contrast to the general population, 18 to 22 year-olds tend to be more liberal, and liberalism among this group is associated with increased trust in others.

We attempt to resolve this inconsistent relationship between ideology and trust by adopting a more meaningful measure of self-rated ideology. Using the 2000 NES, we construct an alternative ideological score that is simply the difference between a respondent's self-rating and their rating of George W. Bush. We prefer this measure since the meaning of the term "liberal" may be sensitive to context; for example, the "liberal" label may have more positive connotations among college-aged individuals than in the general population.

The results in Table 2 demonstrate that the 2000 NES respondents are somewhat more partisan and liberal than the 1972-2002 GSS respondents (this is understandable given the different time periods examined). In addition, Democrats and liberals (however defined) prefer increased government spending. Further, Republicans tend to be more trusting and Democrats less so. However, liberal ideology is only weakly and negatively associated with trust, while our alternative measure of liberal ideology is weakly and positively correlated with trust. We observe a broadly similar pattern for the subset of 18 to 22 year-olds in the NES, although the sample size is quite limited $(\mathrm{n}=30)$ so nearly all of these correlations are insignificant (not

${ }^{6}$ Of course, party alignment has changed over the last 30 years or so, especially in the South, where generalized trust tends to be lower. As a check on this finding, we also examined the GSS data pooled only over the last 15 years or 5 years. While we observe similar patterns in the data, there are fewer significant differences due to the smaller sample size, particularly for the sub-group of 18-22 year olds. 
shown).

Taken together, these national survey results confirm that Democrats and liberals are more likely to favor spending on public programs, while Republicans are more likely to profess trust in others. However, the association between ideology and trust is more ambiguous, particularly when considering the college-aged population or our alternative measure of relative liberalism.

\section{Study Design}

Subjects participated in either a public goods experiment or a trust experiment. For each session a group of eight subjects was recruited from undergraduate classes at the College of William and Mary. The games, which are described below, were repeated for 30 rounds with feedback about others' decisions provided at the end of each round. At the completion of the 30 rounds, one round was randomly chosen to determine earnings. Earnings average $\$ 19.57$ in the public goods game and $\$ 22.21$ in the trust game. Finally, at the end of each experimental session we administered a survey with 42 questions covering demographic characteristics, political attitudes and social capital measures.

We conducted six sessions of the public goods experiment designed by Marwell and Ames (1979). In particular each person in a group of eight was given ten tokens to divide between a private account and a group account (i.e., the public good). The private account earned a return of $\$ 1$ to the individual. Each token contributed to the group account earned $\$ 0.25$ for all eight members of the group. This public goods design is linear in the sense that the return to the group account is a linear function of the total number of tokens in that account. Note that it is individually optimal to put all tokens in the private account (since $\$ 1>\$ 0.25$ ). Additionally, 
it is socially optimal for everyone to put all tokens in the public account (since $8 * \$ 0.25=\$ 2>$ \$1), making this a prisoner's dilemma game.

We conducted 12 sessions of the trust (investment) game designed by Berg, Dickhaut and McCabe (1995). In the trust game one subject (the first mover) was given $\$ 10$ and offered the opportunity to pass some, all or none to a partner (the second mover). All passed money was tripled before being received by the second mover. Finally, the second mover had the opportunity to pass some, all or none of the money he received back to the first mover. Using backward induction, it is straightforward to show that the Nash equilibrium for this game is that no money will be passed in the first stage since second movers have no incentive to return money in the second stage. ${ }^{7}$ Subjects were randomly assigned to be a first mover or a second mover in the game. Roles remained constant throughout the experimental session but subjects were randomly re-paired at the beginning of each new round.

The experimental design is described in Table 3. Note that each session was divided into three blocks of ten rounds. Each block represented a different distribution of fixed show-up payments. ${ }^{8}$ The purpose of this variation in fixed payments was to create a less egalitarian environment that would allow us to test whether the association between liberal ideology and support for public goods or trust is conditioned on the perceived fairness of the social

${ }^{7}$ This analysis applies to a one-shot game, but can also be extended to a repeated game with a known endpoint.

${ }^{8}$ It is a standard practice to pay subjects a fixed fee for showing up for an experiment. This payment supplements what subjects earn based on their decisions and serves as a lower bound on their compensation for participating in the experiment. 
environment. ${ }^{9}$ We considered two inequality treatments, which are described as "skewed" and "symmetric" in Table 3. Note that the average fixed payment is $\$ 7.50$ in all three treatments.

\section{Survey Results}

We next examine the correlations of measures of political party and ideology with attitudinal measures regarding spending and trust among subjects who participated in our public goods and trust experiments ( $\mathrm{n}=144)$. Our survey included four questions pertaining to political ideology. The first asked subjects to indicate the political party to which they belong, and a follow-up question asked subjects to choose the political party that best represents their interests, where available responses included Democrat, Republican, other, and none. Because one-third of the subjects did not report a response to the party membership question, we used the second question to define party interests. As shown in Table 4, 40.3\% of respondents reported that the Democrat party best represents their interests, $37.5 \%$ reported Republican, with the remainder divided among the other party and no party categories. This formulation of party affinity is similar to questions about Democrat or Republican leanings in the GSS and NES. Compared to national opinion then, our experimental subjects were somewhat less partisan, but among partyleaners, slightly more Republican. ${ }^{10}$

To measure political ideology, the survey first asked subjects to rate their ideological

${ }^{9}$ The behavioral effect of heterogeneity in the fixed payments is discussed in Anderson, Mellor and Milyo (2004a and 2004b).

${ }^{10}$ Our survey did not distinguish among minor parties; however, a contemporaneous survey of 190 undergraduates at the College of William and Mary found party identification to breakdown as follows: 50.6\% Democrat, 32.7\% Republican, 10.9\% Independent, $2.9 \%$ Green, $2.3 \%$ Libertarian and $0.6 \%$ Other (www.wm.edu/government/content/spring\%202003 $\% 20$ student $\% 20$ survey.html). 
leanings on a scale from zero to 10 , with zero defined as extreme conservative, five as moderate, and 10 as extreme liberal. Subjects averaged slightly "left" of moderate with a 5.46 on this scale. The survey next instructed subjects to rate President Bush in the same manner; subtracting this rating from the subject's own rating yields our second measure of ideology. On average, subjects in our experiments perceived themselves as more liberal than President Bush. Our subjects were also more liberal than the average of all GSS respondents, but very comparable in this dimension to NES respondents and the subset of college-aged GSS respondents.

Table 4 describes the correlation between political views and either support for government spending or generalized trust among our experimental subjects. One immediate difference between these results and those observed with the national survey data is that party and ideology are more strongly correlated with views on government spending ${ }^{11}$. However, the relative support for spending by Democrats and liberals compared to Republicans and conservatives is more in keeping with the GSS, and to a lesser extent, the NES. Alignment with the Democrat party was positively and significantly correlated with views that government spending overall and on social programs in particular is too low ${ }^{12}$. Significant negative correlations exist between both measures of spending attitudes and subject affinity for the Republican party. Further, the sizes of the correlations between party and social program

\footnotetext{
${ }^{11}$ This suggests that our sample of college students is more consistent than the general public when it comes to matching their political views with preferences about government spending; we speculate that this may be a function of youthful idealism and the increasing polarization of the American electorate.

${ }^{12}$ The survey question for government spending was phrased: "Use the following scale to indicate your opinion about government spending on each program ( $1=$ Too little, $2=$ About right, $3=$ Too much): National defense, foreign aid, welfare, education, transportation, Social Security, Medicare, police and prisons." When looking at attitudes about social programs we used only the responses regarding welfare, education, Social Security, and Medicare.
} 
spending are almost identical to those reported in Table 2 using the NES respondents, a much more recent sample than the pooled GSS sample. The findings reported in Table 4 also indicate that being more liberal in either absolute terms or relative to Bush is positively associated with views that government spending is too low, as was the case in both the GSS and NES.

Consistent with the national surveys, we also find that Republicans are significantly more trusting, and that liberal attitudes negatively correlate with perceptions that most people can be trusted, although the latter are not statistically significant. ${ }^{13}$ Finally, Table 4 reports the correlations between political party and ideology and a question not examined in the GSS or NES -- self-reported trustworthiness. ${ }^{14}$ While $92 \%$ of our subjects view themselves as trustworthy, there are positive and significant correlations between self-reported trustworthiness and both measures of liberal political leanings. Interestingly, Republicans are not more likely to describe themselves as trustworthy, despite articulating a greater amount of trust in others.

In summary, our survey of the opinions of our experimental subjects exhibits similar patterns to those found in national surveys. Consistent with popular belief, Democrats and liberals support increased spending on public programs. However, in contrast to popular wisdom (but consistent with evidence from national surveys), Republicans exhibit more trust and political ideology is only weakly and inconsistently associated with trust. However, our survey of the

13 The survey reads "Generally speaking, would you say that most people can be trusted, or that you can't be too careful in dealing with people?" with available responses of "most people can be trusted", "it depends" and "you can't be too careful in dealing with people." We formed a dichotomous variable equal to 1 for responses for "most people can be trusted" and 0 otherwise.

${ }^{14}$ This question is worded "Do you agree or disagree with the statement: 'I am trustworthy'?". For responses of "strongly agree" and "agree but not strongly," we coded a trustworthiness indicator variable to 1; for responses of "uncertain, or it depends," "disagree but not strongly," and "strongly disagree," we coded the indicator variable as 0. 
experimental subjects reveals a significant positive correlation between liberal ideology and selfreported trustworthiness. We now turn to the question of whether party and ideology affect behavior in public goods and trust games.

\section{Experimental Results}

As a first step, we present descriptive statistics and conduct non-parametric tests on the average play of each individual in our study (see Table 5). From the public goods experiment, we report mean values of the number of tokens contributed by subjects to the group account. This action is thought to reflect the value subjects place on the welfare of other subjects, much like the survey questions on government spending on social programs. From the trust experiments, we report mean amounts sent by first movers, a measure of the level of trust that player has in his or her randomly-matched partner. Finally, we also examine the mean ratio of amount returned to amount available among the second movers, which can be interpreted as the trustworthiness of these subjects. For each subject, we calculate the average decision over 30 rounds, and we then average those values over the 48 subjects that participated in that feature of the experiment. The means for the full sample are reported in Table 5, along with means by the subjects' party and ideology.

Unlike the survey responses on public spending, trust, and trustworthiness, the mean decisions of our subjects do not show marked differences by political party and ideology. For example, in the public goods experiment, subjects with Democratic leanings contributed an average of 2.8 tokens to the group account, and those with Republican leanings contributed only slightly less, or 2.6 tokens. This difference between Democrats and Republicans does not prove to be significant according to a Mann-Whitney test carried out in a sample of only those two 
groups. Morever, in a series of Mann-Whitney tests we conducted for each party and ideology subgroup, we found no significant differences in group account contribution for any one group of subjects relative to the remaining subjects. This same pattern of results is exhibited for both the amount sent decision and the return ratio decision. ${ }^{15}$ There is little discernable difference in trusting behavior between Democrats and Republicans (i.e., amounts sent average 4.52 and 4.51 respectively). While the differences between liberals and non-liberals are somewhat larger at 5.14 versus 4.85 tokens, or 5.49 versus 4.45 tokens, these are not significant according to MannWhitney tests. Trusting behavior is also higher among subjects with other party or no party interests compare to all others, but again those differences are not statistically significant. In the analysis of mean return ratio, conjectured to reflect the subject's trustworthiness, there is a clear tendency among all groups to return roughly one-third of the tokens available. Recall that in the experiment, tokens sent to the second mover were tripled before the return decision was made; thus, the return ratio is strongly associated with the multiplier used in the experimental design. The minor fluctuations by subgroup are not significant according to Mann-Whitney tests.

In contrast to the analysis above, we now conduct multivariate regression analysis of the round-by-round decisions made by the experimental subjects. We analyze these subject decisions in each round of either game using a GLS regression model with random subjectspecific effects; this allows us to control for the influence of subject race and gender in testing for the effects of political leanings. This approach also allows us to test the effects of the inequality treatment in our design. Because the effects of ideology may only be triggered by perceived inequities not visible in an egalitarian laboratory setting, we varied the show-up payments that

${ }^{15}$ We define the "return ratio" as the amount of tokens returned to the first mover relative to the amount available to be returned by the second mover. 
our subjects received within each session. As we described earlier, of the 30 decisions made by subjects in each game, ten were made in settings where all subjects received the same show-up fee of $\$ 7.50$, another ten were made in settings where show-up fees were symmetrically distributed around a mean of $\$ 7.50$, and ten decisions were made with show-up fees that were skewed (one subject received $\$ 20$, but the mean fee remained $\$ 7.50$ ). In both of the nonegalitarian settings, payments were randomly distributed among the subjects. In the regression analyses that follows, we discuss how these inequality treatments affected subject decisions directly, and moreover, we discuss whether inequality affected the associations between political leanings and our subjects' behaviors.

As a check on the appropriateness of the subject-specific random effects model, we test the hypothesis that the estimated coefficients are not systematically different from consistent estimates obtained via a subject-specific fixed effects model. The p-values for these Hausman tests are reported in the last row of all subsequent tables; in no case can we reject the null hypothesis. While this exercise reinforces the appropriateness of random versus fixed effects, it does not rule out alternative models. For example, we could address the potential dependence of decisions made by a given subject by adjusting standard errors for clustering at the level of the individual in OLS estimation. An even more conservative method would be to use subject means across rounds of each experiment as the dependent variable. We discuss the sensitivity of our findings to these two alternative specifications below.

Starting with our public goods experiments, we report results from the random effects GLS regressions of round-by-round contributions to the group account in Table 6 (for political party) and Table 7 (for ideology). Model 1 in each table reports results from a regression 
controlling for subject gender and race, as well as fixed payment amount and the round of play. The omitted category in the party analysis is Republican. These results are substantively similar to our descriptive statistics; that is, none of the political party or ideology measures has a significant association with mean contributions to the group account. In Model 2 of each table, we report results that take into account the unequal nature of the show-up fees; in this case, the indicator variable for an unequal distribution of fixed payments is negative and significant. Elsewhere, we analyze the this effect of inequality on public good provision in greater detail (Anderson, Mellor and Milyo 2004a and 2004b). Once again, the measures of political party (in Table 6) are not individually or jointly significantly associated with group account contributions, nor are the measures of political ideology (in Table 7).

To allow the effects of political leaning to vary with the inequality treatment, we interact each political measure with the inequality indicator. These results are reported as Model 3 in our tables. We continue to find no effect of major political party attachment or liberal ideology on public goods contributions, nor do we find evidence that such political measures interact with the inequality treatment. However, the interaction between other party and inequality is negative and significant in Table 6. Next, Model 4 includes indicators for sessions; ${ }^{16}$ this leads to only one difference from the previous model: now, other party is significantly associated with increased contributions $(\mathrm{p}<.10)$. The effects of minor party affiliation are only reinforced in Model 5 when we add interaction effects between political party and fixed payment (jointly significant at $\mathrm{p}<.05$ ). However, a good deal of caution is in order, as only two individuals in the public goods experiment identify with minor parties. Therefore these anomalous findings for other party

\footnotetext{
${ }^{16}$ The session indicators approach joint significance, with $\mathrm{p}=.12$.
} 
should not distract from the overall finding that while major party and ideological preferences are strongly associated with attitudes about spending on public programs, there is no evidence that such political leanings explain subject behavior in our public goods sessions.

Turning to our series of trust experiments, we next examine the results of random effects GLS regressions of mean amounts sent by the first mover, controlling for subject specific random effects. These results are reported in Table 8 (for political party) and Table 9 (for ideology). We examine the same set of five model specifications as we did in analyzing the public goods data. Results reported in Table 8 suggest that political party has no significant effect on trusting behavior, although the point estimates for other party and no party are large and positive in Model 1 (again, the cell sizes for these cases are small, $n=4$ and 11, respectively). Other than a persistent dampening effect of inequality on trusting behavior, the only statistically significant coefficient is for the interaction of fixed payment and other party (there is also a large and marginally significant effect of other party). In all, these results are quite consistent with those in the public goods experiment, in that there is no evidence that preferences for the two major parties are associated with greater generosity.

However, in some of the models reported in Table 9 we find that subjects who rate themselves as more liberal (or more liberal than President Bush) send significantly higher amounts to their randomly-matched partner. This result is in contrast to the survey responses reported in Table 4, which reveal a negative correlation between liberal views and an attitudinal measure of trust. Looking across the estimates in Models 1-3, the association between liberalism and tokens sent in the trust game is driven by behavior in the inequality treatment; as conjectured, liberals behave differently when the artificial egalitarian structure of the experiment 
is perturbed through variations in fixed payments. This effect persists even when session fixed effects and interactions between ideology and the individual's fixed payment are included as controls (Models 4 and 5, respectively); however, for self-reported ideology the interaction between ideology and inequality is only marginally significant (see panel A of Table 9).

The substantive importance of the association between liberal ideology and tokens sent in the trust game can be assessed by comparing the effects of a one standard deviation change in either self-reported liberalism (2.20 units) or relative liberalism (3.46 units). Using the estimates from Model 4, a one-standard deviation increase in liberal ideology produces an increase in mean tokens sent of about $5 \%$ to $7 \%$, but only in the inequality treatment. The results of Model 5 again demonstrate that this effect is not an artifact of the interaction between ideology and fixed payment; that is, the ideology-inequality effect persists even after controlling for the statistically significant ideology-fixed payment interaction. Finally, the latter interaction is also substantively non-trivial. For example, the estimates in Table 9 imply that moving from the low fixed payment of $\$ 4$ to the high of $\$ 20$ will increase tokens sent by $20 \%$ to $29 \%$ for a subject who is one standard deviation more liberal than the average (by either measure of liberalism).

Our final series of regressions examines the second-movers' decisions in the trust experiments. In Tables 10 and 11 we report the results of random effects GLS models of the number of tokens returned, a behavioral measure analogous to trustworthiness. The independent variables in Models 1-5 are identical to those described above, except that we also control for the amount of tokens available for the second mover to return. Recall that our analysis of survey responses shown in Table 4 found that both measures of liberal ideology were positively and significantly correlated with self-reports of trustworthiness. These results are very similar to 
those already observed in the analysis of tokens sent. In short, we observe a persistent negative effect of inequality on tokens in both Tables 10 and 11; major party leanings are not associated with the return ratio, but minor party is associated with a lower return ratio; and liberal ideology is associated with a significant increase in tokens returned, but only in the inequality treatment. However, the effects of liberalism on tokens returned are substantively much larger; for example, the estimates for Model 5 imply that a one standard deviation increase in liberal ideology (by either measure) will yield an increase in the number of tokens returned of about $7 \%$ to $8 \%$ for liberal second movers in the inequality treatment. ${ }^{17}$

Thus far, we have described only the results obtained from estimating random effects GLS models; this method allows for unobserved heterogeneity across individuals, but assumes that any correlation in the individual-specific disturbance terms do not vary systematically by round. We also estimated two alternative specifications that incorporate different assumptions about the independence of individual-specific disturbance terms across rounds of the experiments. First we re-estimated our models by OLS and adjust the errors for clustering at the level of the individual experimental subject. Second, we treated the individual means across all rounds as the dependent variable and estimate our models by OLS. Both of these methods adopt more conservative assumptions about the independence of the individual specific disturbance terms than the random effects GLS, but sacrifice efficiency. Not surprisingly then, in both cases, we obtain similar point estimates as in the random effects model but with larger standard errors; as a result, the finding that liberals are significantly more trusting and trustworthy in the inequality treatment is not robust to these alternative specifications. However, because the point

${ }^{17}$ In the sample used to estimate the amount returned models, self-reported liberalism has a standard deviation of 1.98 and relative liberalism has a standard deviation of 2.76. 
estimates on liberal ideology are in some cases substantively large, we opt to report in detail the model that yields the most efficient estimates, which is the random effects GLS.

\section{Conclusion}

There exists a common perception that Democrats and liberals are inherently more compassionate or other-regarding than Republicans or conservatives. National survey evidence on attitudes toward public spending and redistribution strongly supports (and likely perpetuates) this stereotype, although survey evidence on generalized trust is not always consistent with the popular wisdom. However, despite the plethora of experimental research conducted using public goods and trust games, no previous published study explicitly tests whether Democrats and liberals do indeed "play nice." We address this lacuna in the scientific literature and put conventional wisdom to the test.

In general, we find that Democrats behave no differently than Republicans in either a canonical public goods game or trust experiment. This stands in contrast to survey evidence in which Democrats describe themselves as more supportive of public goods and Republicans describe themselves as more trusting. As is the case with major party affinity, self-described liberals do not contribute more in the public goods experiment than conservatives. Further, this evidence is robust to alternative model specifications and estimation methods. Surprisingly, minor party affiliation is associated with greater contributions and trustworthiness in these experiments, but the small number of individuals with such leanings and the lack of robustness to the estimation method makes us wary of making too much of this finding. Nevertheless, future work could examine this result more closely by over-sampling subjects with minor party affiliations and distinguishing between specific minor party affiliations. 
In contrast to the above, we do find some evidence from our trust experiment that liberals appear both to trust more (i.e., send more tokens) and to be more trustworthy (i.e., return more tokens). These differences are not observed in the usual egalitarian setting of equal fixed payments for participation; only when we induce inequality through differential fixed payments do we observe a significant effect of liberal ideology on behavior in trust games. Further, this effect is not solely due to increased generosity by liberals who happen to get the high fixed payment. While such "lucky liberals" do send more tokens, the effect of liberal ideology on trust and trustworthiness persists even after controlling for the interaction of fixed payment amount and liberal ideology. Even so, some caution is in order before concluding that liberals play nice.

When we adopt either of the more conservative estimation procedures, we find no significant differences in play by political party or political ideology in either experiment. Consequently, before concluding that liberals are more trusting or trustworthy, more experimental evidence is in order. If this finding holds up to further scrutiny, then we will have identified two possible conundrums: 1) why do liberals behave differently than Democrats? and, 2) why do liberals behave differently in public goods games versus trust games? The first of these is perhaps less puzzling than would appear at first glance, since there are many liberal Republicans and conservative Democrats (e.g., Rudy Giuliani and Zell Miller, respectively). Therefore, the existence of some difference in the apparent importance of political party and political ideology in determining subject behavior in experiments is perhaps not so surprising. However, we leave the latter puzzle to be addressed by future research.

Our results also hold some lessons for experimental research. The disproportionate presence of Democrats and liberals in the most common pools of potential experimental subjects 
(i.e., college students) does not appear to affect the results of public goods or trust games in the typically egalitarian setting of the experimental lab. However, liberal-leaning subjects appear to behave differently once we induce inequality in our trust experiment. This finding, together with the persistent importance of induced inequality itself, suggests that more attention may be needed regarding the importance of the heterogeneity of subjects on experimental results. For example, while our undergraduate subjects were mostly white, middle-class and native citizens, it is not inconceivable that more diverse groups of subjects may influence individual behavior in some experimental settings. Finally, the egalitarian conditions of the experimental lab itself may be a confounding factor that obscures some behavioral regularities. 


\section{References}

Alesina, Alberto and Elianna La Ferrara. 2002. "Who Trusts Others?" Journal of Public Economics, 85(2): 207-34.

Alesina, Alberto and Eliana La Ferrara. 2000. "Participation in Heterogeneous Communities." Quarterly Journal of Economics, 115 (3): 847-904

Anderson, Lisa R., Jennifer M. Mellor, and Jeffrey Milyo. 2004a. "Social Capital and Contributions in a Public Goods Experiment." American Economic Review Papers and Proceedings, 94 (2): 373-376.

Anderson, Lisa R., Jennifer M. Mellor, and Jeffrey Milyo. 2004b. "Inequality, Group Cohesion and Public Good Provision.” Working Paper, Department of Economics, The College of William and Mary.

Berg, Joyce, John Dickhaut and Kevin McCabe. 1995. "Trust, Reciprocity, and Social History." Games and Economic Behavior, 10: 122-142.

Colmes, Alan. 2003. Red, White and Blue. Regan Books: New York.

Coulter, Ann. 2002. “Battered Republican Syndrome,” AnnCoulter.com (August 28, 2002); viewed at www.anncoulter.org/columns/2002/082802.htm on May 25, 2004.

Fehr, Ernst, and Urs Fischbacher, Bernhard von Rosenbladt, Jurgen Schupp, and Gert G. Wagner. 2003. "A Nation-Wide Laboratory: Examining Trust and Trustworthiness by Integrating Behavioral Experiments into Representative Surveys." IZA Discussion Paper No. 715 (February 2003), Bonn, Germany.

Frey, Bruno S. and Stephan Meier. 2003. "Are Political Economists selfish and Indoctrinated? Evidence from a Natural Experiment," Economic Inquiry, 41(30: 448-462.

Glaeser, Edward L., David I. Laibson, Jose A. Scheinkman, and Christine L. Soutter. 2000. "Measuring Trust.” Quarterly Journal of Economics, 115 (3): 811-846.

Marwell, Gerald and Ruth Ames. 1979. "Experiments on the Provision of Public Goods I: Resources, Interest, Group Size and the Free-Rider Problem." American Journal of Sociology, 84(6): 1335-60.

Mestelman, Stuart and David Feeney. 1988. "Does Ideology Matter? Anecdotal Experimental Evidence on the Voluntary Provision of Public Goods," Public Choice, 57(2): 287-294. 
Ostrom, Elinor and James Walker. 2003. Trust and Reciprocity: Interdisciplinary Lessons from Experimental Research. Russell Sage Foundation: New York.

PBS Think Tank, “Can Conservatives be Compassionate?” Transcript from December 21, 1995; viewed at www.pbs.org/thinktank/transcript239.htm on May 25, 2004.

Putnam, Robert. 2000. Bowling Alone. Simon and Schuster (New York, New York).

Wilson, James Q. and John J. DiIulio, Jr. (2004). American Government, $9^{\text {th }}$ edition. Houghton Mifflin: Boston. 
Table 1. Correlations in Survey Responses in General Social Survey, 1972-2002

\begin{tabular}{|c|c|c|c|c|}
\hline & Mean & $\begin{array}{c}\text { Number of } 8 \text { programs } \\
\text { with "too little" } \\
\text { government spending }\end{array}$ & $\begin{array}{l}\text { Number of } 4 \text { social } \\
\text { programs with "too little" } \\
\text { government spending }\end{array}$ & $\begin{array}{l}\text { Agree that } \\
\text { "most people } \\
\text { can be trusted" }\end{array}$ \\
\hline \multicolumn{5}{|c|}{ Panel A: All respondents $(n=24,198)$} \\
\hline $\begin{array}{l}\text { Democrat or } \\
\text { Democrat leaning }\end{array}$ & 0.49 & $0.08^{* * *}$ & $0.10^{* * *}$ & $-0.04^{* * *}$ \\
\hline $\begin{array}{l}\text { Republican or } \\
\text { Republican leaning }\end{array}$ & 0.36 & $-0.09^{* * *}$ & $-0.11^{* * *}$ & $0.08^{* * *}$ \\
\hline Independent & 0.13 & $0.01^{*}$ & $0.01^{*}$ & $-0.05^{* * *}$ \\
\hline $\begin{array}{l}\text { Liberal (normalized } \\
\text { to } 0-10 \text { point scale) }\end{array}$ & 5.08 & $0.07^{* * *}$ & $0.11^{* * *}$ & $-0.01^{*}$ \\
\hline \multicolumn{5}{|c|}{ Panel B: 18 to 22 year-olds only $(n=1,555)$} \\
\hline $\begin{array}{l}\text { Democrat or } \\
\text { Democrat leaning }\end{array}$ & 0.45 & $0.06^{* *}$ & $0.09^{* * *}$ & 0.00 \\
\hline $\begin{array}{l}\text { Republican or } \\
\text { Republican leaning }\end{array}$ & 0.36 & $-0.06^{* *}$ & $-0.08^{* * *}$ & $0.04^{* *}$ \\
\hline Independent & 0.18 & 0.01 & 0.02 & $-0.05^{* *}$ \\
\hline $\begin{array}{l}\text { Liberal (normalized } \\
\text { to } 0-10 \text { point scale) }\end{array}$ & 5.60 & 0.03 & $0.08^{* * *}$ & $0.06^{* *}$ \\
\hline
\end{tabular}

Notes: Significant correlations between variables indicated by ${ }^{* * *}$ for $\mathrm{p}<0.01,{ }^{* *}$ for $\mathrm{p}<0.05,{ }^{*}$ for $\mathrm{p}<0.10$. 
Table 2. Correlations in Survey Responses in National Election Study, 2000

\begin{tabular}{lccc}
\hline \hline & Mean & $\begin{array}{c}\text { Agree that "Government } \\
\text { should increase spending and } \\
\text { services" }\end{array}$ & $\begin{array}{c}\text { Agree that "most } \\
\text { people can be } \\
\text { trusted" }\end{array}$ \\
\hline Democrat or Democrat leaning & 0.51 & $0.39^{* * *}$ & $-0.07^{* *}$ \\
Republican or Republican leaning & 0.40 & $-0.43^{* * *}$ & $0.08^{* *}$ \\
Independent & 0.09 & 0.03 & 0.01 \\
$\begin{array}{l}\text { Liberal (normalized range is } 0 \text { to } \\
10 \text { points) }\end{array}$ & 6.28 & $0.21^{* * *}$ & -0.05 \\
$\begin{array}{l}\text { Liberal relative to Bush } \\
\text { (normalized range is }-10 \text { to }+10)\end{array}$ & 2.69 & $0.16^{* * *}$ & 0.01 \\
\hline \hline
\end{tabular}

Notes: Significant correlations between variables indicated by ${ }^{* * *}$ for $\mathrm{p}<0.01,{ }^{* *}$ for $\mathrm{p}<0.05,{ }^{*}$ for $\mathrm{p}<0.10$. 
Table 3. Experimental Design

\begin{tabular}{cccccc}
\hline \hline Session & Experiment & $\begin{array}{c}\text { Block } 1 \\
(10 \text { rounds })\end{array}$ & $\begin{array}{c}\text { Block } 2 \\
(10 \text { rounds })\end{array}$ & $\begin{array}{c}\text { Block 3 } \\
(10 \text { rounds })\end{array}$ & $\begin{array}{c}\text { Number of } \\
\text { Subjects }\end{array}$ \\
\hline $1-2$ & Public Goods & Egalitarian & Skewed & Symmetric & 16 \\
$3-4$ & Public Goods & Skewed & Symmetric & Egalitarian & 16 \\
$5-6$ & Public Goods & Symmetric & Egalitarian & Skewed & 16 \\
& & Total Subjects in the Public Goods Experiment & 48 \\
$7-10$ & Trust & Egalitarian & Skewed & Symmetric & 32 \\
$11-14$ & Trust & Skewed & Symmetric & Egalitarian & 32 \\
$15-18$ & Trust & Symmetric & Egalitarian & Skewed & 32 \\
& & \multicolumn{2}{c}{ Total Subjects in the Trust Experiment } & 96 \\
\hline \hline
\end{tabular}

Notes: Egalitarian show-up payments=(8@ @7.50)

Skewed show-up payments=(1@\$20,4@\$7,3@\$4)

Symmetric show-up payments=(3@\$10,2@\$7.50, $3 @ \$ 5)$ 
Table 4. Correlations in Survey Responses among Subjects in Public Goods and Trust Experiments

\begin{tabular}{|c|c|c|c|c|c|}
\hline & Mean & $\begin{array}{l}\text { Number of } 8 \\
\text { government } \\
\text { programs in } \\
\text { which spending is } \\
\text { "too little" }\end{array}$ & $\begin{array}{c}\text { Number of } 4 \\
\text { social programs } \\
\text { in which } \\
\text { spending is "too } \\
\text { little" }\end{array}$ & $\begin{array}{l}\text { Agrees } \\
\text { that "most } \\
\text { people } \\
\text { can be } \\
\text { trusted" }\end{array}$ & $\begin{array}{c}\text { Describes } \\
\text { oneself as } \\
\text { "trust- } \\
\text { worthy" }\end{array}$ \\
\hline $\begin{array}{l}\text { Democratic Party Best } \\
\text { Represents Interests }\end{array}$ & 0.403 & $0.33^{* * *}$ & $0.38^{* * *}$ & -0.07 & 0.02 \\
\hline $\begin{array}{l}\text { Republican Party } \\
\text { Best Represents } \\
\text { Interests }\end{array}$ & 0.375 & $-0.36^{* * *}$ & $-0.44^{* * *}$ & $0.18^{* *}$ & -0.05 \\
\hline $\begin{array}{l}\text { Other Party Best } \\
\text { Represents Interests }\end{array}$ & 0.069 & $0.24^{* * *}$ & $0.26^{* * *}$ & 0.06 & 0.08 \\
\hline $\begin{array}{l}\text { No Party Best } \\
\text { Represents Interests }\end{array}$ & 0.153 & -0.13 & -0.11 & $-0.19^{* *}$ & -0.02 \\
\hline $\begin{array}{l}\text { 11-point Ideology Scale } \\
(0=\text { extreme } \\
\text { conservative, } \\
10=\text { extreme liberal })\end{array}$ & 5.46 & $0.45^{* * *}$ & $0.55^{* * *}$ & -0.08 & $0.14^{*}$ \\
\hline \multirow{2}{*}{$\begin{array}{l}\text { Ideology Difference } \\
\text { (own rating less Bush } \\
\text { rating) }\end{array}$} & 2.51 & $0.45^{* * *}$ & $0.53^{* * *}$ & -0.12 & $0.20^{* *}$ \\
\hline & Mean: & 3.09 & 2.37 & 0.30 & 0.92 \\
\hline
\end{tabular}

Notes: Sample means and correlations are based on 144 subjects, except for three variables with a few missing values: spending preferences for government and social programs ( $\mathrm{n}=140$ and 141, respectively) and ideological difference with President Bush $(n=143)$. Significant correlations between variables indicated by ${ }^{* * *}$ for $\mathrm{p}<0.01,{ }^{* *}$ for $\mathrm{p}<0.05,{ }^{*}$ for $\mathrm{p}<0.10$. 
Table 5. Mean Subject Decisions in Public Goods and Trust Experiments, By Political Party and Ideology

\begin{tabular}{|c|c|c|c|}
\hline & $\begin{array}{c}\text { Public Goods } \\
\text { Experiment }\end{array}$ & \multicolumn{2}{|c|}{ Trust Experiment } \\
\hline & $\begin{array}{l}\text { Mean Group Account } \\
\text { Contribution }\end{array}$ & $\begin{array}{l}\text { Mean Tokens Sent to } \\
\text { Second Mover }\end{array}$ & $\begin{array}{l}\text { Mean Ratio of } \\
\text { Tokens Returned to } \\
\text { First Mover to } \\
\text { Tokens Available }\end{array}$ \\
\hline All Subjects & $\begin{array}{l}2.75 \\
(1.58) \\
n=48\end{array}$ & $\begin{array}{c}4.97 \\
(2.60) \\
n=48\end{array}$ & $\begin{array}{c}0.35 \\
(0.17) \\
n=48\end{array}$ \\
\hline $\begin{array}{l}\text { Democratic Party Best } \\
\text { Represents Interests }\end{array}$ & $\begin{array}{l}2.78 \\
(1.57) \\
\mathrm{n}=18\end{array}$ & $\begin{array}{c}4.52 \\
(2.20) \\
n=15\end{array}$ & $\begin{array}{c}0.35 \\
(0.17) \\
n=25\end{array}$ \\
\hline $\begin{array}{l}\text { Republican Party Best } \\
\text { Represents Interests }\end{array}$ & $\begin{array}{l}2.60 \\
(1.55) \\
n=21\end{array}$ & $\begin{array}{c}4.51 \\
(2.71) \\
n=18\end{array}$ & $\begin{array}{c}0.35 \\
(0.19) \\
n=15\end{array}$ \\
\hline $\begin{array}{l}\text { Other Party Best } \\
\text { Represents Interests }\end{array}$ & $\begin{array}{c}3.12 \\
(0.45) \\
n=2\end{array}$ & $\begin{array}{c}6.40 \\
(2.77) \\
n=4\end{array}$ & $\begin{array}{c}0.33 \\
(0.10) \\
n=4\end{array}$ \\
\hline $\begin{array}{l}\text { No Party Best Represents } \\
\text { Interests }\end{array}$ & $\begin{array}{c}3.01 \\
(2.10) \\
\mathrm{n}=7\end{array}$ & $\begin{array}{c}5.82 \\
(2.83) \\
\mathrm{n}=11\end{array}$ & $\begin{array}{c}0.38 \\
(0.28) \\
n=4\end{array}$ \\
\hline $\begin{array}{l}\text { Liberal } \\
\text { (Equal to } 1 \text { for values of } 6 \\
\text { or higher on } 11 \text {-point } \\
\text { scale, } 0 \text { otherwise) }\end{array}$ & $\begin{array}{c}2.62 \\
(1.51) \\
n=19\end{array}$ & $\begin{array}{l}5.14 \\
(2.76) \\
n=20\end{array}$ & $\begin{array}{c}0.34 \\
(0.17) \\
n=32\end{array}$ \\
\hline $\begin{array}{l}\text { More Liberal Than Bush } \\
\text { (Equal to } 1 \text { if ideology } \\
\text { difference exceeds sample } \\
\text { mean, } 0 \text { otherwise) }\end{array}$ & $\begin{array}{l}2.74 \\
(1.53) \\
n=20\end{array}$ & $\begin{array}{c}5.49 \\
(2.46) \\
n=24\end{array}$ & $\begin{array}{c}0.33 \\
(0.17) \\
n=27\end{array}$ \\
\hline
\end{tabular}

Notes: Mean values of subject choices taken over 30 decision making periods in the experiment. 
Table 6. Effects of Political Party on Group Account Contributions

\begin{tabular}{|c|c|c|c|c|c|}
\hline & Model 1 & Model 2 & Model 3 & Model 4 & Model 5 \\
\hline Fixed Payment & $\begin{array}{l}0.024 \\
(0.99)\end{array}$ & $\begin{array}{l}0.024 \\
(1.00)\end{array}$ & $\begin{array}{l}0.026 \\
(1.07)\end{array}$ & $\begin{array}{l}0.025 \\
(1.06)\end{array}$ & $\begin{array}{l}0.004 \\
(0.11)\end{array}$ \\
\hline Democratic Party & $\begin{array}{l}0.365 \\
(0.65)\end{array}$ & $\begin{array}{l}0.365 \\
(0.65)\end{array}$ & $\begin{array}{l}0.400 \\
(0.67)\end{array}$ & $\begin{array}{r}-0.043 \\
(0.07)\end{array}$ & $\begin{array}{l}0.023 \\
(0.03)\end{array}$ \\
\hline Other Party & $\begin{array}{l}0.510 \\
(0.42)\end{array}$ & $\begin{array}{l}0.510 \\
(0.42)\end{array}$ & $\begin{array}{l}1.853 \\
(1.43)\end{array}$ & $\begin{array}{l}2.161^{*} \\
(1.66)\end{array}$ & $\begin{array}{l}4.809^{* *} \\
(2.17)\end{array}$ \\
\hline No Party & $\begin{array}{l}0.408 \\
(0.57)\end{array}$ & $\begin{array}{l}0.408 \\
(0.57)\end{array}$ & $\begin{array}{l}0.770 \\
(1.01)\end{array}$ & $\begin{array}{l}0.063 \\
(0.08)\end{array}$ & $\begin{array}{l}-1.167 \\
(1.21)\end{array}$ \\
\hline Unequal Treatment & & $\begin{array}{c}-0.386^{* * *} \\
(3.10)\end{array}$ & $\begin{array}{l}-0.203 \\
(-1.05)\end{array}$ & $\begin{array}{l}-0.203 \\
(1.05)\end{array}$ & $\begin{array}{l}-0.204 \\
(1.05)\end{array}$ \\
\hline $\begin{array}{l}\text { Unequal* } \\
\text { Democratic Party }\end{array}$ & & & $\begin{array}{l}-0.053 \\
(0.18)\end{array}$ & $\begin{array}{l}-0.053 \\
(0.18)\end{array}$ & $\begin{array}{l}-0.059 \\
(0.21)\end{array}$ \\
\hline Unequal*Other Party & & & $\begin{array}{c}-2.016^{* * *} \\
(3.12)\end{array}$ & $\begin{array}{c}-2.015^{* * *} \\
(3.12)\end{array}$ & $\begin{array}{c}-1.618^{* *} \\
(2.36)\end{array}$ \\
\hline Unequal*No Party & & & $\begin{array}{l}-0.542 \\
(1.40)\end{array}$ & $\begin{array}{l}-0.543 \\
(1.40)\end{array}$ & $\begin{array}{l}-0.481 \\
(1.24)\end{array}$ \\
\hline $\begin{array}{l}\text { Fixed Payment } * \\
\text { Democratic Party }\end{array}$ & & & & & $\begin{array}{l}-0.006 \\
(0.12)\end{array}$ \\
\hline $\begin{array}{l}\text { Fixed Payment * } \\
\text { Other Party }\end{array}$ & & & & & $\begin{array}{l}-0.357 \\
(1.50)\end{array}$ \\
\hline $\begin{array}{l}\text { Fixed Payment * } \\
\text { No Party }\end{array}$ & & & & & $\begin{array}{l}0.170^{* *} \\
(2.44)\end{array}$ \\
\hline $\begin{array}{l}\text { Includes Session } \\
\text { Fixed Effects }\end{array}$ & No & No & No & Yes & Yes \\
\hline Hausman Test p-value & 1.000 & 1.000 & 1.000 & 1.000 & 1.000 \\
\hline
\end{tabular}

Notes: All models are based on a sample of 1440 observations. Coefficients from Random Effects GLS models are reported, with absolute values of t-statistics in parentheses. All models include controls for the round of play, and race and gender of the subject. Statistical significance is indicated by: ${ }^{* * *}$ for the 0.01 level, ${ }^{* *}$ for the 0.05 level, and ${ }^{*}$ for the 0.10 level. 
Table 7. Effects of Political Ideology on Group Account Contributions

\begin{tabular}{|c|c|c|c|c|c|}
\hline \multicolumn{6}{|c|}{ PANEL A: Ideology Scale $(\mathrm{n}=1440)$} \\
\hline & Model 1 & Model 2 & Model 3 & Model 4 & Model 5 \\
\hline Fixed Payment & $\begin{array}{l}0.024 \\
(0.99)\end{array}$ & $\begin{array}{l}0.024 \\
(1.00)\end{array}$ & $\begin{array}{l}0.025 \\
(1.03)\end{array}$ & $\begin{array}{l}0.025 \\
(1.07)\end{array}$ & $\begin{array}{c}0.066 \\
(0.83)\end{array}$ \\
\hline $\begin{array}{l}\text { Ideology Scale }(0= \\
\text { extreme conservative, } \\
10=\text { extreme liberal })\end{array}$ & $\begin{array}{l}-0.015 \\
(0.12)\end{array}$ & $\begin{array}{l}-0.015 \\
(0.12)\end{array}$ & $\begin{array}{l}0.018 \\
(0.13)\end{array}$ & $\begin{array}{l}-0.091 \\
(0.67)\end{array}$ & $\begin{array}{r}-0.035 \\
(0.21)\end{array}$ \\
\hline Unequal Treatment & & $\begin{array}{c}-0.386^{* * *} \\
(3.10)\end{array}$ & $\begin{array}{l}-0.133 \\
(0.36)\end{array}$ & $\begin{array}{l}-0.132 \\
(0.36)\end{array}$ & $\begin{array}{l}-0.121 \\
(0.33)\end{array}$ \\
\hline $\begin{array}{l}\text { Unequal*Ideology } \\
\text { Scale }\end{array}$ & & & $\begin{array}{l}-0.050 \\
(0.74)\end{array}$ & $\begin{array}{l}-0.050 \\
(0.74)\end{array}$ & $\begin{array}{l}-0.051 \\
(0.76)\end{array}$ \\
\hline $\begin{array}{l}\text { Fixed Payment* } \\
\text { Ideology Scale }\end{array}$ & & & & & $\begin{array}{l}-0.007 \\
(0.53)\end{array}$ \\
\hline $\begin{array}{l}\text { Includes Session } \\
\text { Fixed Effects }\end{array}$ & No & No & No & Yes & Yes \\
\hline Hausman Test $p$-value & 1.000 & 1.000 & 1.000 & 1.000 & 1.000 \\
\hline \multicolumn{6}{|c|}{ PANEL B: Ideology Difference $(\mathrm{n}=1410)$} \\
\hline & Model 1 & Model 2 & Model 3 & Model 4 & Model 5 \\
\hline Fixed Payment & $\begin{array}{r}0.023 \\
(0.94)\end{array}$ & $\begin{array}{r}0.023 \\
(0.95)\end{array}$ & $\begin{array}{l}0.023 \\
(0.95)\end{array}$ & $\begin{array}{r}0.023 \\
(0.95)\end{array}$ & $\begin{array}{l}-0.007 \\
(0.23)\end{array}$ \\
\hline $\begin{array}{l}\text { Ideology Difference } \\
\text { (own rating less Bush } \\
\text { rating) }\end{array}$ & $\begin{array}{l}-0.043 \\
(0.40)\end{array}$ & $\begin{array}{l}-0.043 \\
(0.40)\end{array}$ & $\begin{array}{l}-0.016 \\
(0.15)\end{array}$ & $\begin{array}{l}-0.096 \\
(0.89)\end{array}$ & $\begin{array}{l}-0.210 \\
(1.61)\end{array}$ \\
\hline Unequal Treatment & & $\begin{array}{c}-0.400^{* * *} \\
(3.16)\end{array}$ & $\begin{array}{l}-0.318^{*} \\
(1.83)\end{array}$ & $\begin{array}{l}-0.318^{*} \\
(1.83)\end{array}$ & $\begin{array}{r}-0.300^{*} \\
(1.72)\end{array}$ \\
\hline $\begin{array}{l}\text { Unequal*Ideology } \\
\text { Difference }\end{array}$ & & & $\begin{array}{l}-0.040 \\
(0.69)\end{array}$ & $\begin{array}{l}-0.040 \\
(0.69)\end{array}$ & $\begin{array}{l}-0.048 \\
(0.83)\end{array}$ \\
\hline $\begin{array}{l}\text { Fixed Payment * } \\
\text { Ideology Difference }\end{array}$ & & & & & $\begin{array}{l}0.015 \\
(1.57)\end{array}$ \\
\hline $\begin{array}{l}\text { Includes Session } \\
\text { Fixed Effects }\end{array}$ & No & No & No & Yes & Yes \\
\hline Hausman Test p-value & 1.000 & 1.000 & 1.000 & 1.000 & 1.000 \\
\hline
\end{tabular}

Notes: Coefficients from Random Effects GLS models reported, with absolute values of t-statistics in parentheses. All models include controls for the round of play, and race and gender of the subject. Statistical significance is indicated by: ${ }^{* * *}$ for the 0.01 level, ${ }^{* *}$ for the 0.05 level, and ${ }^{*}$ for the 0.10 level. 
Table 8. Effects of Political Party on Tokens Sent

\begin{tabular}{|c|c|c|c|c|c|}
\hline & Model 1 & Model 2 & Model 3 & Model 4 & Model 5 \\
\hline Fixed Payment & $\begin{array}{l}0.024 \\
(0.90)\end{array}$ & $\begin{array}{l}0.028 \\
(1.03)\end{array}$ & $\begin{array}{l}0.031 \\
(1.16)\end{array}$ & $\begin{array}{l}0.028 \\
(1.04)\end{array}$ & $\begin{array}{l}0.037 \\
(0.99)\end{array}$ \\
\hline Democratic Party & $\begin{array}{l}0.302 \\
(0.32)\end{array}$ & $\begin{array}{l}0.306 \\
(0.33)\end{array}$ & $\begin{array}{l}-0.041 \\
(0.04)\end{array}$ & $\begin{array}{r}0.215 \\
(0.20)\end{array}$ & $\begin{array}{l}0.836 \\
(0.69)\end{array}$ \\
\hline Other Party & $\begin{array}{l}2.215 \\
(1.50)\end{array}$ & $\begin{array}{l}2.221 \\
(1.51)\end{array}$ & $\begin{array}{l}1.888 \\
(1.24)\end{array}$ & $\begin{array}{l}-0.155 \\
(-0.09)\end{array}$ & $\begin{array}{l}3.064 \\
(1.52)\end{array}$ \\
\hline No Party & $\begin{array}{l}1.589 \\
(1.56)\end{array}$ & $\begin{array}{l}1.589 \\
(1.56)\end{array}$ & $\begin{array}{l}1.226 \\
(1.17)\end{array}$ & $\begin{array}{l}0.892 \\
(0.81)\end{array}$ & $\begin{array}{l}0.387 \\
(0.33)\end{array}$ \\
\hline Unequal Treatment & & $\begin{array}{c}-0.353^{* *} \\
(2.45)\end{array}$ & $\begin{array}{c}-0.686^{* * *} \\
(2.90)\end{array}$ & $\begin{array}{c}-0.683^{* * *} \\
(2.89)\end{array}$ & $\begin{array}{c}-0.696^{* * *} \\
(2.94)\end{array}$ \\
\hline $\begin{array}{l}\text { Unequal* } \\
\text { Democratic Party }\end{array}$ & & & $\begin{array}{l}0.527 \\
(1.48)\end{array}$ & $\begin{array}{l}0.523 \\
(1.47)\end{array}$ & $\begin{array}{l}0.511 \\
(1.44)\end{array}$ \\
\hline Unequal*Other Party & & & $\begin{array}{l}0.510 \\
(0.92)\end{array}$ & $\begin{array}{l}0.502 \\
(0.90)\end{array}$ & $\begin{array}{l}-0.083 \\
(0.14)\end{array}$ \\
\hline Unequal*No Party & & & $\begin{array}{r}0.545 \\
(1.42)\end{array}$ & $\begin{array}{l}0.545 \\
(1.42)\end{array}$ & $\begin{array}{l}0.480 \\
(1.24)\end{array}$ \\
\hline $\begin{array}{l}\text { Fixed Payment } * \\
\text { Democratic Party }\end{array}$ & & & & & $\begin{array}{l}-0.086 \\
(1.11)\end{array}$ \\
\hline $\begin{array}{l}\text { Fixed Payment * } \\
\text { Other Party }\end{array}$ & & & & & $\begin{array}{c}-0.436^{* * *} \\
(2.76)\end{array}$ \\
\hline $\begin{array}{l}\text { Fixed Payment * } \\
\text { No Party }\end{array}$ & & & & & $\begin{array}{l}0.068 \\
(1.04)\end{array}$ \\
\hline $\begin{array}{l}\text { Includes Session } \\
\text { Fixed Effects }\end{array}$ & No & No & No & Yes & Yes \\
\hline Hausman Test p-value & 1.000 & 1.000 & 1.000 & 1.000 & 1.000 \\
\hline
\end{tabular}

Notes: All models are based on a sample of 1440 observations. Coefficients from Random Effects GLS models are reported, with absolute values of t-statistics in parentheses. All models include controls for the round of play, and race and gender of the subject. Statistical significance is indicated by: ${ }^{* * *}$ for the 0.01 level, ${ }^{* *}$ for the 0.05 level, and ${ }^{*}$ for the 0.10 level. 
Table 9. Effects of Political Ideology on Tokens Sent

\begin{tabular}{|c|c|c|c|c|c|}
\hline \multicolumn{6}{|c|}{ PANEL A: Ideology Scale $(\mathrm{n}=1440)$} \\
\hline & Model 1 & Model 2 & Model 3 & Model 4 & Model 5 \\
\hline Fixed Payment & $\begin{array}{l}0.026 \\
(0.95)\end{array}$ & $\begin{array}{l}0.029 \\
(1.08)\end{array}$ & $\begin{array}{l}0.037 \\
(1.36)\end{array}$ & $\begin{array}{l}0.033 \\
(1.23)\end{array}$ & $\begin{array}{l}-0.082 \\
(1.40)\end{array}$ \\
\hline $\begin{array}{l}\text { Ideology Scale }(0= \\
\text { extreme conservative, } \\
10=\text { extreme liberal })\end{array}$ & $\begin{array}{l}0.284^{*} \\
(1.65)\end{array}$ & $\begin{array}{l}0.285^{*} \\
(1.66)\end{array}$ & $\begin{array}{l}0.206 \\
(1.16)\end{array}$ & $\begin{array}{l}0.081 \\
(0.42)\end{array}$ & $\begin{array}{l}-0.136 \\
(0.62)\end{array}$ \\
\hline Unequal Treatment & & $\begin{array}{c}-0.353^{* *} \\
(2.45)\end{array}$ & $\begin{array}{c}-0.996^{* * *} \\
(2.63)\end{array}$ & $\begin{array}{c}-0.988^{* * *} \\
(2.61)\end{array}$ & $\begin{array}{c}-0.877^{* *} \\
(2.30)\end{array}$ \\
\hline $\begin{array}{l}\text { Unequal*Ideology } \\
\text { Scale }\end{array}$ & & & $\begin{array}{l}0.122^{*} \\
(1.83)\end{array}$ & $\begin{array}{l}0.120^{*} \\
(1.82)\end{array}$ & $\begin{array}{l}0.107 \\
(1.62)\end{array}$ \\
\hline $\begin{array}{l}\text { Fixed Payment* } \\
\text { Ideology Scale }\end{array}$ & & & & & $\begin{array}{l}0.029^{* *} \\
(2.22)\end{array}$ \\
\hline $\begin{array}{l}\text { Includes Session } \\
\text { Fixed Effects }\end{array}$ & No & No & No & Yes & Yes \\
\hline Hausman Test p-value & 1.000 & 1.000 & 1.000 & 1.000 & 1.000 \\
\hline \multicolumn{6}{|c|}{ PANEL B: Ideology Difference $(\mathrm{n}=1440)$} \\
\hline & Model 1 & Model 2 & Model 3 & Model 4 & Model 5 \\
\hline Fixed Payment & $\begin{array}{l}0.025 \\
(0.93)\end{array}$ & $\begin{array}{l}0.028 \\
(1.06)\end{array}$ & $\begin{array}{l}0.033 \\
(1.24)\end{array}$ & $\begin{array}{l}0.030 \\
(1.11)\end{array}$ & $\begin{array}{l}-0.003 \\
(0.10)\end{array}$ \\
\hline $\begin{array}{l}\text { Ideology Difference } \\
\text { (own rating less Bush } \\
\text { rating) }\end{array}$ & $\begin{array}{l}0.209^{*} \\
(1.94)\end{array}$ & $\begin{array}{l}0.209^{*} \\
(1.94)\end{array}$ & $\begin{array}{l}0.144 \\
(1.29)\end{array}$ & $\begin{array}{l}0.000 \\
(0.00)\end{array}$ & $\begin{array}{l}-0.197 \\
(1.38)\end{array}$ \\
\hline Unequal Treatment & & $\begin{array}{c}-0.353^{* *} \\
(2.45)\end{array}$ & $\begin{array}{c}-0.596^{* * *} \\
(3.35)\end{array}$ & $\begin{array}{c}-0.594^{* * *} \\
(3.34)\end{array}$ & $\begin{array}{c}-0.545^{* * *} \\
(3.07)\end{array}$ \\
\hline $\begin{array}{l}\text { Unequal*Ideology } \\
\text { Difference }\end{array}$ & & & $\begin{array}{l}0.098^{* *} \\
(2.33)\end{array}$ & $\begin{array}{l}0.098^{* *} \\
(2.32)\end{array}$ & $\begin{array}{l}0.091^{* *} \\
(2.17)\end{array}$ \\
\hline $\begin{array}{l}\text { Fixed Payment } * \\
\text { Ideology Difference }\end{array}$ & & & & & $\begin{array}{c}0.026^{* * *} \\
(3.11)\end{array}$ \\
\hline $\begin{array}{l}\text { Includes Session } \\
\text { Fixed Effects }\end{array}$ & No & No & No & Yes & Yes \\
\hline Hausman Test p-value & 1.000 & 1.000 & 1.000 & 1.000 & 1.000 \\
\hline
\end{tabular}

Notes: Coefficients from Random Effects GLS models reported, with absolute values of t-statistics in parentheses. All models include controls for the round of play, and race and gender of the subject. Statistical significance is indicated by: ${ }^{* * *}$ for the 0.01 level, ${ }^{* *}$ for the 0.05 level, and ${ }^{*}$ for the 0.10 level. 
Table 10. Effects of Political Party on Tokens Returned

\begin{tabular}{|c|c|c|c|c|c|}
\hline & Model 1 & Model 2 & Model 3 & Model 4 & Model 5 \\
\hline Fixed Payment & $\begin{array}{l}-0.015 \\
(0.39)\end{array}$ & $\begin{array}{c}-0.019 \\
(0.48)\end{array}$ & $\begin{array}{r}-0.015 \\
(0.38)\end{array}$ & $\begin{array}{l}-0.014 \\
(0.36)\end{array}$ & $\begin{array}{r}-0.060 \\
(0.65)\end{array}$ \\
\hline Democratic Party & $\begin{array}{l}0.276 \\
(0.31)\end{array}$ & $\begin{array}{l}0.275 \\
(0.30)\end{array}$ & $\begin{array}{l}-0.110 \\
(0.12)\end{array}$ & $\begin{array}{l}0.295 \\
(0.24)\end{array}$ & $\begin{array}{l}-0.045 \\
(0.03)\end{array}$ \\
\hline Other Party & $\begin{array}{l}-0.407 \\
(0.27)\end{array}$ & $\begin{array}{l}-0.406 \\
(0.27)\end{array}$ & $\begin{array}{l}-1.348 \\
(0.83)\end{array}$ & $\begin{array}{r}-1.987 \\
(0.90)\end{array}$ & $\begin{array}{l}-6.982^{* *} \\
(2.53)\end{array}$ \\
\hline No Party & $\begin{array}{l}0.684 \\
(0.42)\end{array}$ & $\begin{array}{l}0.686 \\
(0.42)\end{array}$ & $\begin{array}{l}1.138 \\
(0.67)\end{array}$ & $\begin{array}{l}1.087 \\
(0.51)\end{array}$ & $\begin{array}{l}0.921 \\
(0.42)\end{array}$ \\
\hline Unequal Treatment & & $\begin{array}{l}-0.324 \\
(1.64)\end{array}$ & $\begin{array}{l}-0.685^{*} \\
(1.91)\end{array}$ & $\begin{array}{l}-0.687^{*} \\
(1.92)\end{array}$ & $\begin{array}{c}-0.711^{* *} \\
(1.97)\end{array}$ \\
\hline $\begin{array}{l}\text { Unequal* } \\
\text { Democratic Party }\end{array}$ & & & $\begin{array}{l}0.578 \\
(1.28)\end{array}$ & $\begin{array}{l}0.578 \\
(1.28)\end{array}$ & $\begin{array}{l}0.606 \\
(1.33)\end{array}$ \\
\hline Unequal*Other Party & & & $\begin{array}{l}1.413^{*} \\
(1.79)\end{array}$ & $\begin{array}{l}1.414^{*} \\
(1.79)\end{array}$ & $\begin{array}{l}1.800^{* *} \\
(2.23)\end{array}$ \\
\hline Unequal*No Party & & & $\begin{array}{l}-0.682 \\
(0.88)\end{array}$ & $\begin{array}{l}-0.679 \\
(0.87)\end{array}$ & $\begin{array}{l}-0.644 \\
(0.82)\end{array}$ \\
\hline $\begin{array}{l}\text { Fixed Payment } * \\
\text { Democratic Party }\end{array}$ & & & & & $\begin{array}{l}0.041 \\
(0.39)\end{array}$ \\
\hline $\begin{array}{l}\text { Fixed Payment * } \\
\text { Other Party }\end{array}$ & & & & & $\begin{array}{c}0.670^{* * *} \\
(2.56)\end{array}$ \\
\hline $\begin{array}{l}\text { Fixed Payment * } \\
\text { No Party }\end{array}$ & & & & & $\begin{array}{l}0.025 \\
(0.18)\end{array}$ \\
\hline $\begin{array}{l}\text { Includes Session } \\
\text { Fixed Effects }\end{array}$ & No & No & No & Yes & Yes \\
\hline Hausman Test p-value & 1.000 & 1.000 & 1.000 & 1.0000 & 0.999 \\
\hline
\end{tabular}

Notes: All models are based on a sample of 1440 observations. Coefficients from Random Effects GLS models are reported, with absolute values of t-statistics in parentheses. All models include controls for the amount available to return, the round of play, and race and gender of the subject. Statistical significance is indicated by: ${ }^{* * *}$ for the 0.01 level, ${ }^{* *}$ for the 0.05 level, and ${ }^{*}$ for the 0.10 level. 
Table 11. Effects of Political Ideology on Tokens Returned

\begin{tabular}{|c|c|c|c|c|c|}
\hline \multicolumn{6}{|c|}{ PANEL A: Ideology Scale $(\mathrm{n}=1440)$} \\
\hline & Model 1 & Model 2 & Model 3 & Model 4 & Model 5 \\
\hline Fixed Payment & $\begin{array}{l}-0.015 \\
(0.38)\end{array}$ & $\begin{array}{l}-0.019 \\
(0.47)\end{array}$ & $\begin{array}{l}-0.020 \\
(0.51)\end{array}$ & $\begin{array}{l}-0.020 \\
(0.51)\end{array}$ & $\begin{array}{l}-0.026 \\
(0.17)\end{array}$ \\
\hline $\begin{array}{l}\text { Ideology Scale }(0= \\
\text { extreme conservative, } \\
10=\text { extreme liberal })\end{array}$ & $\begin{array}{l}0.104 \\
(0.51)\end{array}$ & $\begin{array}{l}0.104 \\
(0.51)\end{array}$ & $\begin{array}{l}-0.028 \\
(0.13)\end{array}$ & $\begin{array}{l}-0.056 \\
(0.21)\end{array}$ & $\begin{array}{l}-0.064 \\
(0.20)\end{array}$ \\
\hline Unequal Treatment & & $\begin{array}{r}-0.324 \\
(1.64)\end{array}$ & $\begin{array}{c}-1.507^{* *} \\
(2.33)\end{array}$ & $\begin{array}{c}-1.510^{* *} \\
(2.34)\end{array}$ & $\begin{array}{c}-1.512^{* *} \\
(2.34)\end{array}$ \\
\hline $\begin{array}{l}\text { Unequal*Ideology } \\
\text { Scale }\end{array}$ & & & $\begin{array}{l}0.198^{*} \\
(1.92)\end{array}$ & $\begin{array}{l}0.198^{*} \\
(1.93)\end{array}$ & $\begin{array}{l}0.198^{*} \\
(1.93)\end{array}$ \\
\hline $\begin{array}{l}\text { Fixed Payment* } \\
\text { Ideology Scale }\end{array}$ & & & & & $\begin{array}{l}0.001 \\
(0.04)\end{array}$ \\
\hline $\begin{array}{l}\text { Includes Session } \\
\text { Fixed Effects }\end{array}$ & No & No & No & Yes & Yes \\
\hline Hausman Test p-value & 1.000 & 1.000 & 1.000 & 1.000 & 1.000 \\
\hline \multicolumn{6}{|c|}{ PANEL B: Ideology Difference $(\mathrm{n}=1440)$} \\
\hline & Model 1 & Model 2 & Model 3 & Model 4 & Model 5 \\
\hline Fixed Payment & $\begin{array}{l}-0.015 \\
(0.38)\end{array}$ & $\begin{array}{l}-0.018 \\
(0.47)\end{array}$ & $\begin{array}{l}-0.021 \\
(0.55)\end{array}$ & $\begin{array}{l}-0.021 \\
(0.55)\end{array}$ & $\begin{array}{l}-0.070 \\
(0.92)\end{array}$ \\
\hline $\begin{array}{l}\text { Ideology Difference } \\
\text { (own rating less Bush } \\
\text { rating) }\end{array}$ & $\begin{array}{l}-0.054 \\
(0.38)\end{array}$ & $\begin{array}{l}-0.054 \\
(0.38)\end{array}$ & $\begin{array}{l}-0.160 \\
(1.06)\end{array}$ & $\begin{array}{l}-0.208 \\
(1.18)\end{array}$ & $\begin{array}{l}-0.314 \\
(1.37)\end{array}$ \\
\hline Unequal Treatment & & $\begin{array}{l}-0.324 \\
(1.64)\end{array}$ & $\begin{array}{c}-0.797^{* * *} \\
(2.71)\end{array}$ & $\begin{array}{c}-0.799^{* * *} \\
(2.72)\end{array}$ & $\begin{array}{c}-0.853^{* * *} \\
(2.82)\end{array}$ \\
\hline $\begin{array}{l}\text { Unequal*Ideology } \\
\text { Difference }\end{array}$ & & & $\begin{array}{l}0.158^{* *} \\
(2.17)\end{array}$ & $\begin{array}{l}0.159^{* *} \\
(2.17)\end{array}$ & $\begin{array}{c}0.173^{* *} \\
(2.29)\end{array}$ \\
\hline $\begin{array}{l}\text { Fixed Payment * } \\
\text { Ideology Difference }\end{array}$ & & & & & $\begin{array}{l}0.014 \\
(0.75)\end{array}$ \\
\hline $\begin{array}{l}\text { Includes Session } \\
\text { Fixed Effects }\end{array}$ & No & No & No & Yes & Yes \\
\hline Hausman Test p-value & 1.000 & 1.000 & 1.000 & 1.00 & 0.929 \\
\hline
\end{tabular}

Notes: Coefficients from Random Effects GLS models reported, with absolute values of t-statistics in parentheses. All models include controls for the amount available to return, the round of play, and race and gender of the subject. Statistical significance is indicated by: ${ }^{* * *}$ for the 0.01 level, ${ }^{* *}$ for the 0.05 level, and ${ }^{*}$ for the 0.10 level. 